\title{
About The Interconnection Between Erythropoietin, Mononuclears And Colon Carcinoma Cells
}

\author{
Hanna Bessler ${ }^{1,3}$, Michal Herman-Edelstein ${ }^{2,3}$ and Meir Djaldetti ${ }^{1,3 *}$ \\ ${ }^{1}$ Laboratory for Immunology and Hematology Research, Rabin Medical Center Hasharon Hospital, Petah-Tiqva \\ ${ }^{2}$ Felsenstein Medical Research Center and Department of Nephrology Rabin Medical Center, Petah-Tiqva
}

${ }^{3}$ Sackler School of Medicine, Tel-Aviv University, Ramat Aviv, Israel

Received: September 24, 2018; Accepted: October 8, 2018; Published: October 9, 2018

*Corresponding author: Meir Djaldetti, Laboratory for Immunology and Hematology Research, Rabin Medical Center, Hasharon Hospital, 7, Keren Kayemet St, Petah Tiqva, Israel, Phone: 972-3-9372480;Fax: 972-3-9372398; E-mail: hannab@clalit.org.il

\begin{abstract}
Background: Erythropoietin regulates erythropoiesis, express immune modulatory effects and it is suggested to be linked to tumorigenesis. We evaluated the effect of erythropoietin on the proliferation capacity of human peripheral blood mononuclear cells (PBMC) and colon carcinoma cells, detected its ability to induce production of inflammatory cytokines and assessed a possible impact on the cross-talk between immune and cancer cells.

Methods: Non-stimulated human PBMC or cells stimulated with either mitogen or with HT-29 and RKO colon cancer cells were incubated for $24 \mathrm{hrs}$ without or with various doses of erythropoietin and the concentration of TNF $\alpha$, IL-1 $\beta$, IL-6, IFN $\gamma$, IL-2, IL-10 and IL-1ra in the supernatants was detected.

Results: EPO caused increased secretion of TNF $\alpha$, IL- $1 \beta$, IL6, IFN $\gamma$ and IL-2 by RKO-stimulated PBMC, as well as IFN $\gamma$ and IL-2 induced by PMA/ionomycin and TNF $\alpha$ production by non-stimulated or HT-29 stimulated PBMC. The production of anti-inflammatory cytokines was not affected by EPO.

Conclusions: The enhancement of inflammatory cytokine secretion by PBMC incubated with colon cancer cells in the presence of erythropoietin indicates that the hormone is able to activate the immune cross-talk between these two types of cells. These findings enlighten the relationship between immune and colon cancer cells of certain lines.
\end{abstract}

Keywords: Erythropoietin; Mononuclear Cells; Cytokines; Colon Cancer Cells

\section{Introduction}

Since centuries, medical practice has advanced concomitantly with newer therapeutic and research discoveries which improved markedly physicians' options for treating patients and to prolong human life. In that sense the short length of time from the assumption that there is a substance responsible for regulation of erythropoiesis and creation of human recombinant erythropoietin was amazing. During the seventies, one of the authors (MD) had the "privilege" to study various effects of human urinary erythropoietin which at those times was quite difficult to obtain. The history of this vital protein that is actually a cytokine is masterly detailed in a review by Bunn [1]. With a remarkably swiftness, researchers came to conclusion that the erythroid-stimulating hormone, designated as erythropoietin (EPO) is produced manly, but not solely in the kidney. Eventually, it has been shown that EPO in the plasma binds to receptors located on the erythroid progenitors' surface. Notable EPO exerts a hypoxia-protective effect in other organs such as brain, heart, liver, as wells as endothelial cells, a process thoroughly described in previous reports [1-3]. Studies have shown that there is a close relationship between EPO and immunity. Based on encouraging activity of EPO on the immune status of animals in murine myeloma models, it was forwarded as a treatment modality in patients with multiple myeloma and altered immune system observed at the early stages of the disease [4, 5]. It has been reported that EPO affects CD4 (+) and CD8 (+) cell proliferation activity proceeding though EPO- receptors located on their surface [6]. Using human T-lymphocytes activated with antibodies against human CD2, CD3 and CD28 Todosenko et al. [7] have obtained a significant increase in IL-2, IL-4 and IL-10 production. Similar effect on IL-2 production has been observed in whole blood cell cultures from patients under hemodialysis [8]. Incubation of monocytes with EPO resulted in an increase of their phagocytic ability, as well as a decreased production of IL- 6 and TNF [9]. Later on, an antitumor activity has been attributed to EPO in addition to its role as a regulator of red blood cell production. Based on the observation that treatment of anemia in patients with multiple myeloma resulted in a marked improvement in quality and longevity of life, Mittelman et al. $[10,11]$ examined the effect of EPO on a murine myeloma model and observed that EPO treated animals showed better survival and lower mortality compared to untreated mice. Further studies indicated that the anti-myeloma effect of recombinant EPO in those patients is at least in part due to an activation of the immune system expressed by reduced IL-6 to normal levels and normalization of CD4:CD8 cell ratio [4]. Moreover, it was found that patients treated with EPO showed increased levels of pro-angiogenetic cytokines indicating a promoting effect of EPO on the capacity 
of macrophages to produce pro-angiogenetic factors [12]. The question arises if the stimulating effect of EPO on erythropoiesis may be expressed also on malignant cells with a consequent accelerated proliferation. Studies have shown that although serum EPO levels are increased in patients with colorectal cancer, its effect on malignant cell proliferation remains uncertain. Recombinant human erythropoietin exerted an inhibitory effect on DLD-1 human colon carcinoma cells growth and proliferation with an increase in their EPO receptors [13]. The aim of the current study was to evaluate the effect of erythropoietin on the proliferation of colon cancer cells of two lines and of human peripheral blood mononuclear cells (PBMC), on its capacity to affect $\mathrm{PBMC}$ to produce inflammatory cytokines and its impact on the cross-talk between immune and cancer cells.

\section{Materials and Methods}

\section{Peripheral blood mononuclear cells (PBMC)}

Buffy coats isolated from blood bank donors' blood were purchased from Magen David Adom, Blood Services Center in Israel. The donors gave written informed consent and an agreement that blood components can be used for medical research. PBMC were separated by Lymphoprep-1077 (AxisShield PoC AS, Oslo, Norway) gradient centrifugation. The cells were washed twice in phosphate buffered saline (PBS) and suspended in RPMI-1640 medium containing 1\% penicillin, streptomycin and nystatin, 10\% fetal bovine serum (FBS), (Biological Industries, Beith Haemek, Israel) and was designated as complete medium (CM).

\section{Colon cancer cell lines}

HT-29 and RKO human colon cancer cell lines were obtained from American Type Cultural Collection, Rockville, MD. The cells were maintained in CM containing Mc-Coy's 5A medium and Dulbecco modified eagle medium (DMEM) respectively, supplemented with 10\% FBS, $2 \mathrm{mM}$ L-glutamine and antibiotics (penicillin, streptomycin and nystatin-Biological Industries Co, Beith-Haemek, Israel). The cells were grown in T-75 culture flasks at $37^{\circ} \mathrm{C}$ in a humidified atmosphere containing $5 \% \mathrm{CO}_{2}$. Both cell lines adhere to the flasks and were removed using trypsin/EDTA solution (Biological Industries Co, Beith-Haemek, Israel.

\section{Erythropoietin (EPO)}

Recombinant erythropoietin (EPO, Binocrit -Epoietin alpha, Sandoz GmbH, Kundl, Austria), was acquired at a concentration of $8000 \mathrm{IU} / 0.8 \mathrm{ml}$. Further dilutions were prepared in CM. The hormone was added to cultures at final concentrations of 0.06 $\mathrm{IU} / \mathrm{ml}, 0.125 \mathrm{IU} / \mathrm{ml}$ and $0.5 \mathrm{IU} / \mathrm{ml}$.

\section{Effect of EPO on cell proliferation}

The effect of EPO on PBMC and colon cancer cells proliferation was determined using XTT proliferation assay kit (Biological Industries, Beith Haemek, Israel). Briefly, $0.1 \mathrm{ml}$ aliquots of PBMC or colon cancer cells $\left(10^{5} / \mathrm{ml}\right.$ of $\left.\mathrm{CM}\right)$ obtained after trypsinization and suspended in appropriate CM, were added to each one of 96 well plates and incubated for $24 \mathrm{hrs}$ in absence or presence of EPO at concentrations as indicated. At the end of the incubation period the cells were stained according to the manufacturer's instructions. The plates were incubated for $2-4 \mathrm{hrs}$ at $37^{\circ} \mathrm{C}$ in a humidified incubator containing $5 \% \mathrm{CO}_{2}$ and the absorbance was measured at $450 \mathrm{~nm}$ using ELISA reader.

\section{Effect of EPO on cytokine production}

$2 \times 10^{6}$ PBMC suspended in $1 \mathrm{ml}$ of CM were incubated in 24 well plated (Nunc, Thermo Fisher Scientific, Paisley PA4 9RF, UK) without (control) or with EPO at final concentrations as indicated. EPO was added at the onset of the cultures. The cultures were incubated without or with $50 \mathrm{ng} / \mathrm{ml}$ of lipopolysaccharide (LPS, E. coli, Sigma) to determine the effect of EPO on TNF $\alpha$, IL-1 $\beta$, IL6, IL-1ra and IL-10 and with PMA $1 \mu \mathrm{g} / \mathrm{ml}$ and ionomycin $0.5 \mu \mathrm{g} /$ $\mathrm{ml}$ (Sigma, Israel) for IL-2 and IFN $\gamma$ secretion. In another set of experiments, HT-29 or RKO cells were collected from the flasks by typsinization and were suspended in appropriated CM at $4 \times 10^{5} / \mathrm{ml}$. The cells were seeded in 24 well plates by addition of $0.5 \mathrm{ml}$ of cell suspension to each well. The plates were incubated for $60 \mathrm{~min}$ at $37^{\circ} \mathrm{C}$ in a humidified atmosphere containing $5 \%$ $\mathrm{CO}_{2}$. Consequently, $0.5 \mathrm{ml}$ aliquots of PBMC suspended in $\mathrm{CM}$ $\left(4 \times 10^{6} / \mathrm{ml}\right)$ were added to each well. The cells were incubated without or with EPO at $0.06,0.125$ and $0.5 \mathrm{IU} / \mathrm{ml}$, added at the onset of cultures. All cultures were maintained for $24 \mathrm{hrs}$ at $37^{\circ} \mathrm{C}$ in a humidified atmosphere containing $5 \% \mathrm{CO}_{2}$. At the end of the incubation period, the culture media were collected, the cells were removed by centrifugation at $200 \mathrm{~g}$ for $10 \mathrm{~min}$ and the supernatants were kept at $-70^{\circ} \mathrm{C}$ until assayed for cytokine content.

\section{Cytokine content in the supernatants}

The concentration of cytokines in the supernatants was tested using ELISA kits specific for human cytokines (Biosource International, Camarillo, $\mathrm{CA}$ ) as detailed in the guide-line provided by the manufacturer. The detection level of all cytokines was $30 \mathrm{pg} / \mathrm{ml}$.

\section{Statistical analysis}

A linear mixed model with repeated measures and assumption of compound symmetry (CS) was used to assess the effect of different concentrations of EPO on cytokine secretion by non-stimulated or stimulated PBMC. SAS vs. 9.4 were applied for this analysis. Paired t-test was used to compare between the level of cytokines produced following incubation with various concentrations of EPO and that found in control cultures. Probability values of $\mathrm{p}<0.05$ were considered as significant. The results are expressed as mean \pm SEM.

\section{Results}

\section{Effect of EPO on cell proliferation}

EPO added at concentrations between 0.06 and $0.5 \mathrm{IU} / \mathrm{ml}$ for 24 hrs to either PBMC or colon cancer cells of the two lines had no effect on cell proliferation as tested by XTT assay (data not shown). 


\section{Effect of EPO on cytokine secretion by colon cancer} cells

No detectable amounts of any of the cytokines examined could be found in the supernatants obtained from $24 \mathrm{hrs}$ of cultures of either HT-29 or RKO cells incubated at the above mentioned conditions without or with EPO at concentrations between 0.06 and $0.5 \mathrm{IU} / \mathrm{ml}$.

\section{Effect of EPO on IL-1 $\beta$, IL-6 and IFN $\gamma$ production (Table} 1)

The secretion of TNF $\alpha$ by non-stimulated PBMC was enhanced upon incubation with EPO at the above mentioned concentrations $(\mathrm{p}=0.006)$, and was higher by $33 \%$ and $19 \%$ at EPO concentrations of 0.06 and $0.125 \mathrm{IU} / \mathrm{ml}(\mathrm{p}<0.005)$. TNF $\alpha$ production by LPSstimulated PBMC and that of IL-1 $\beta$ or IL- 6 production by either non-stimulated or LPS-stimulated PBMC was not affected by 24 hrs of incubation with EPO ( $p=0.49, p=0.58, p=0.28$, respectively). EPO caused a slight enhancement in TNF $\alpha$ production induced by HT-29 colon cancer cells ( $\mathrm{p}=0.013$ ) being higher by $2.5 \%$ and $4.2 \%$ at EPO concentrations of 0.125 and $0.5 \mathrm{IU} / \mathrm{ml}$, respectively $(p<0.05)$, whereas that induced by RKO cells was not affected $(p=0.176)$. IL-1 $\beta$ and IL- 6 synthesis by PBMC induced by HT-29 cells was not affected upon incubation with EPO ( $p=0.42$ and $\mathrm{p}=0.62$, respectively). However that induced by RKO cells was slightly increased $(\mathrm{p}=0.006$ and $\mathrm{p}<0.001$, respectively) and was higher by $5 \%$ at EPO concentration of $0.06 \mathrm{IU} / \mathrm{ml}(\mathrm{p}<0.05)$.

Table 1: Effect of EPO on pro-inflammatory cytokine production by PBMC

\begin{tabular}{|c|c|c|c|c|}
\hline & Non-stimulated & LPS-stimulated & HT-29-induced & RKO-induced \\
\hline EPO concentration & \multicolumn{4}{|l|}{$\mathrm{TNF} \alpha, \mathrm{pg} / \mathrm{ml}$} \\
\hline $\mathbf{0}$ & $163 \pm 8$ & $1154 \pm 122$ & $1719 \pm 28$ & $1781 \pm 20$ \\
\hline $0.06 \mathrm{IU} / \mathrm{ml}$ & $217 \pm 9$ & $1097 \pm 158$ & $1771 \pm 32 \mathrm{EPO}$ & $1732 \pm 10$ \\
\hline $0.125 \mathrm{IU} / \mathrm{ml}$ & $194 \pm 6$ & $1114 \pm 153$ & $1759 \pm 31$ & $1752 \pm 21$ \\
\hline $0.5 \mathrm{IU} / \mathrm{ml}$ & $176 \pm 9$ & $1116 \pm 133$ & $1792 \pm 19$ & $1770 \pm 22$ \\
\hline Repeated measures & $\mathrm{F} 3,15=15.19, P=<0.001$ & $\mathrm{~F} 3,15=0.83, P=0.49$ & $\mathrm{~F} 3,15=5.04, P=0.013$ & $\mathrm{~F} 3,15=1.88, P=0.176$ \\
\hline EPO concentration & \multicolumn{4}{|l|}{ IL-1 $\beta, \mathrm{ng} / \mathrm{ml}$} \\
\hline $\mathbf{0}$ & $0.49 \pm 0.12$ & $6.04 \pm 0.78$ & $10.27 \pm 0.11$ & $10.24 \pm 0.19$ \\
\hline $0.06 \mathrm{IU} / \mathrm{ml}$ & $0.38 \pm 0.08$ & $6.19 \pm 0.59$ & $9.96 \pm 0.23$ & $10.73 \pm 0.18$ \\
\hline $0.125 \mathrm{IU} / \mathrm{ml}$ & $0.46 \pm 0.15$ & $5.69 \pm 0.65$ & $10.06 \pm 0.25$ & $10.41 \pm 0.22$ \\
\hline Repeated measures & $\mathrm{F} 3,15=0.67, P=0.58$ & $\mathrm{~F} 3,15=1.37, P=0.28$ & $\mathrm{~F} 3,15=1.0, P=0.42$ & $\mathrm{~F} 3,15=6.19, P=0.006$ \\
\hline EPO concentration & \multicolumn{4}{|l|}{ IL-6, ng/ml } \\
\hline $\mathbf{0}$ & $1.52 \pm 0.47$ & $22.65 \pm 1.06$ & $29.35 \pm 0.37$ & $29.15 \pm 0.58$ \\
\hline $0.06 \mathrm{IU} / \mathrm{ml}$ & $1.46 \pm 0.49$ & $23.58 \pm 0.74$ & $28.44 \pm 0.67$ & $30.69 \pm 0.47$ \\
\hline $0.125 \mathrm{IU} / \mathrm{ml}$ & $1.84 \pm 0.73$ & $25.68 \pm 1.63$ & $28.68 \pm 0.64$ & $29.49 \pm 0.6$ \\
\hline $0.5 \mathrm{IU} / \mathrm{ml}$ & $1.30 \pm 0.42$ & $22.93 \pm 0.92$ & $29.49 \pm 0.82$ & $28.76 \pm 0.55$ \\
\hline Repeated measures & $\mathrm{F} 3,15=1.72, P=0.21$ & $\mathrm{~F} 3,15=1.62, P=0.23$ & $\mathrm{~F} 3,15=0.6, P=0.62$ & $\mathrm{~F} 5,15=9.74, P<0.001$ \\
\hline
\end{tabular}

Non-stimulated PBMC or cells stimulated with either LPS or with one of the colon cancer cell lines HT-29 or RKO, were incubated for 24 hrs without (0) or with EPO at concentrations as indicated. The level of cytokines in the supernatants was tested by ELISA. The results are expressed as Mean \pm SEM of 6 experiments. Asterisks represent statistically significant difference from cells incubated without EP0 ( $p<0.05, p<0.01, p<0.001)$.

\section{Effect of EPO on IL-2 and IFN $\gamma$ production (Table 2)}

While no detectable levels of IL-2 could be found in supernatants of non-stimulated PBMC incubated for $24 \mathrm{hrs}$ without or with EPO, the secretion of IL-2 by PMA/ionomycin stimulated PBMC was increased $(\mathrm{p}=0.001)$ and was higher by $20 \%, 11 \%$ and $8 \%$ at $0.06,0.125$ and $0.5 \mathrm{IU} / \mathrm{ml}$ of EPO, respectively $(\mathrm{p}<0.05)$. Upon incubation with EPO, the secretion of IL-2 induced by HT-29 colon cancer cells was slightly increased reaching borderline significance $(\mathrm{p}=0.06)$, whereas that induced by RKO was stimulated $(\mathrm{p}<0.001)$, and was enhanced by $31 \%$, $20 \%(\mathrm{p}<0.005)$ and $10.9 \%(\mathrm{p}=0.055)$, respectively.
IFN $\gamma$ production by non-stimulated or HT-29 stimulated PBMC was not affected by EPO ( $\mathrm{p}=0.58$ and $\mathrm{p}=0.39$, respectively). The secretion of IFN $\gamma$ by PMA/ionomycin stimulated PBMC was increased $(\mathrm{p}=0.017)$ and at $0.06 \mathrm{IU} / \mathrm{ml}$ of EPO was higher by $27.5 \%(p<0.05)$. While HT-29-induced IFN $\gamma$ secretion was not affected following $24 \mathrm{hrs}$ of incubation with EPO ( $\mathrm{p}=0.39$ ), that induced by RKO cells was stimulated $(\mathrm{p}<0.001)$ and increased by $31 \%$ and $20 \%(\mathrm{p}<0.015)$ at 0.06 and $0.125 \mathrm{IU} / \mathrm{ml}$ of EPO. 
Table 2: Effect of EPO on IL-2 and IFN $\gamma$ production by PBMC

IFN $\gamma, \mathbf{n g} / \mathrm{ml}$

\begin{tabular}{|c|c|c|c|c|}
\hline EPO concentration & Non-stimulated & PMA-stimulated & HT-29-induced & RKO-induced \\
\hline $\mathbf{0}$ & $0.71 \pm 0.09$ & $26.50 \pm 2.91$ & $8.66 \pm 0.25$ & $7.37 \pm 0.29$ \\
\hline $\mathbf{0 . 0 6} \mathbf{~ I U} / \mathbf{m l}$ & $0.64 \pm 0.04$ & $33.80 \pm 4.96$ & $8.33 \pm 0.44$ & $9.66 \pm 0.17$ \\
\hline $\mathbf{0 . 1 2 5} \mathbf{~ I U} / \mathbf{m l}$ & $0.64 \pm 0.04$ & $28.45 \pm 2.00$ & $8.74 \pm 0.54$ & $8.85 \pm 0.43$ \\
\hline $\mathbf{0 . 5} \mathbf{~ I U} / \mathbf{m l}$ & $0.67 \pm 0.05$ & $26.01 \pm 2.48$ & $8.99 \pm 0.42$ & $7.74 \pm 0.26$ \\
\hline Repeated measures & $\mathrm{F} 3,15=1.3, P=0.58$ & $\mathrm{~F} 3,15=4.65, P=0.017$ & $\mathrm{~F} 3,15=1.07, P=0.39$ & $\mathrm{~F} 3,15=17.6, P<0.001$ \\
\hline
\end{tabular}

\section{IL-2, ng/ml}

\begin{tabular}{|c|c|c|c|c|}
\hline $\mathbf{0}$ & - & $18.26 \pm 3.78$ & $3.11 \pm 0.16$ & $2.74 \pm 0.10$ \\
\hline $\mathbf{0 . 0 6} \mathbf{~ I U} / \mathbf{m l}$ & - & $22.03 \pm 3.64$ & $3.12 \pm 0.16$ & $3.59 \pm 0.06$ \\
\hline $\mathbf{0 . 1 2 5} \mathbf{~ I U} / \mathbf{m l}$ & - & $20.39 \pm 3.69$ & $3.34 \pm 0.14$ & $3.31 \pm 0.15$ \\
\hline $\mathbf{0 . 5} \mathbf{~ I U} / \mathbf{m l}$ & - & $19.70 \pm 3.54$ & $3.39 \pm 0.13$ & $3.04 \pm 0.14 \dagger$ \\
\hline Repeated measures & - & $\mathrm{F} 3,15=9.25, P=0.001$ & $\mathrm{~F} 3,15=3.06, P=0.06$ & $\mathrm{~F} 3,15=12.34, P=<0.001$ \\
\hline
\end{tabular}

Non-stimulated PBMC or cells stimulated with either PMA and ionomycin, or with one of the colon cancer cell lines HT-29 or RKO, were incubated for $24 \mathrm{hrs}$ without (0) or with EPO at concentrations as indicated. The level of cytokines in the supernatants was tested by ELISA. The results are expressed as Mean \pm SEM of 6 experiments. Asterisks represent statistically significant difference from cells incubated without EPO $(p<0.05, p<0.01$, $t p=0.07)$.

\section{Effect of EPO on IL-10 and IL-1ra production (Table 3)}

There was no significant effect of EPO on IL-10 or IL-1ra production by non-stimulated or LPS-stimulated PBMC incubated for $24 \mathrm{hrs}$ with EPO at concentrations as indicated ( $\mathrm{p}=0.51$ and $\mathrm{p}=0.63$, respectively). IL-10 secretion by PBMC stimulated with either HT-29 or RKO cells was not affected following incubation with EPO at the above mentioned concentrations $(\mathrm{p}=0.77$ or $\mathrm{p}=0.23$, respectively), nor did IL-1ra production by cells with RKOstimulated PBMC $(\mathrm{p}=0.28)$. However, IL-1ra synthesis by PBMC stimulated with HT-29 cells was slightly increased ( $\mathrm{p}=0.032)$, and was higher by $6 \%$ and $5 \%(\mathrm{p}<0.05)$ at EPO concentrations of 0.06 and $0.125 \mathrm{IU} / \mathrm{ml}$, respectively.

Table 3: Effect of EPO on anti-inflammatory cytokine production by PBMC

IL-10, ng/ml

\begin{tabular}{|c|c|c|c|c|}
\hline EPO concentration & Non-stimulated & LPS-stimulated & HT-29-induced & RKO-induced \\
\hline $\mathbf{0}$ & $0.20 \pm 0.03$ & $1.94 \pm 0.09$ & $1.83 \pm 0.05$ & $1.87 \pm 0.03$ \\
\hline $\mathbf{0 . 0 6} \mathbf{~ I U} / \mathbf{m l}$ & $0.21 \pm 0.02$ & $1.96 \pm 0.16$ & $1.84 \pm 0.07$ & $1.85 \pm 0.03$ \\
\hline $\mathbf{0 . 1 2 5} \mathbf{~ I U} / \mathbf{m l}$ & $0.21 \pm 0.04$ & $2.01 \pm 0.13$ & $1.84 \pm 0.05$ & $1.82 \pm 0.04$ \\
\hline $\mathbf{0 . 5} \mathbf{~ I U} / \mathbf{m l}$ & $0.18 \pm 0.02$ & $1.86 \pm 0.16$ & $1.87 \pm 0.06$ & $1.87 \pm 0.04$ \\
\hline Repeated measures & $\mathrm{F} 3,15=0.8, P=0.51$ & $\mathrm{~F} 3,15=0.58, P=0.63$ & $\mathrm{~F} 3,15=0.38, P=0.77$ & $\mathrm{~F} 3,15=1.57, P=0.23$ \\
\hline
\end{tabular}

IL-1ra, ng/ml

\begin{tabular}{|c|c|c|c|c|}
\hline $\mathbf{0}$ & $1.64 \pm 0.08$ & $1.86 \pm 0.04$ & $2.50 \pm 0.05$ & $2.61 \pm 0.05$ \\
\hline $\mathbf{0 . 0 6} \mathbf{~ I U} / \mathbf{m l}$ & $1.60 \pm 0.06$ & $1.94 \pm 0.06$ & $2.65 \pm 0.07$ & $2.75 \pm 0.06$ \\
\hline $\mathbf{0 . 1 2 5} \mathbf{~ I U} / \mathbf{m l}$ & $1.58 \pm 0.06$ & $1.86 \pm 0.04$ & $2.62 \pm 0.06$ & $2.66 \pm 0.10$ \\
\hline $\mathbf{0 . 5} \mathbf{~ I U} / \mathbf{m l}$ & $1.56 \pm 0.04$ & $1.82 \pm 0.04$ & $2.54 \pm 0.08$ & $2.58 \pm 0.07$ \\
\hline Repeated measures & F 3,15=0.84, $P=0.49$ & F 3,15=, 0.88, $P=0.47$ & F 3,15=3.82, $P=0.03$ & F 3,15=1.42, $P=0.27$ \\
\hline
\end{tabular}

Non-stimulated PBMC or cells stimulated with either LPS or with one of the colon cancer cell lines HT-29 or RKO, were incubated for 24 hrs without (0) or with EPO at concentrations as indicated. The level of cytokines in the supernatants was tested by ELISA. The results are expressed as Mean \pm SEM of 6 experiments. Asterisks represent statistically significant difference from cells incubated without EPO $(\mathrm{p}<0.05)$. 


\section{Discussion}

Studies indicate that EPO is involved not only in regulation of erythropoiesis, but may be implicated in carcinogenesis through a few ways. Since colorectal cancer cells possess erythropoietin receptors it is conceivable that EPO may promote cancer cells' growth and even to stimulate EPO production by malignant cells. Moreover, it has been reported that in colorectal cancer patients EPO levels are higher than those in healthy individuals, although this finding might be associated with hypoxemia caused by anemia usually present in this condition [14]. Chronic inflammation may affect erythropoiesis and EPO activity by activation of proinflammatory cytokines [15]. In our hands EPO did not affect cell proliferation of PBMC and both types of malignant colon cells. This observation is in line with those by Neuman et al. [16] who did not detect any effect of EPO on the number of polymorphonuclears and monocytes in dialysis patients and by Patterson et al. [17] who did not obtain any proliferation of tumor cells from 186 patients with various cancers under the effect of EPO. The authors concluded that there are not EPO receptors at least on the tumor cells examined. Similar findings were reported by investigators working with breast carcinoma models [18], HCT-116 human colon carcinoma, CT-26 mouse colon carcinoma [19] and B16F10 melanoma cells [20]. Moreover, recombinant erythropoietin did not trigger increased proliferation of breast cancer cells, although they expressed EPO receptors [21]. It is plausible therefore, that although there are certain hints that EPO and its receptor correlate with tumor progression [22] there are doubts as for their activity as tumor promoters.

The reports as for the effect of EPO on the production of inflammatory cytokine by LPS stimulated cells are rather inconsistent since it has been found that it may be expressed as inhibition, stimulation or even as lack of effect [23]. The results of the present study indicate that EPO incubated with non-stimulated PBMC caused an increased secretion of TNF $\alpha$ only and did not have any effect on LPS stimulated cells. On the other hand, EPO incubated with PBMC stimulated with PMA/ ionomycin induced increased production of IL- 2 and IFN $\gamma$. These findings are in accordance with previous reports indicating that EPO is able to directly stimulate IL-2 production by whole blood cell cultures $[8,24]$ and to increase IFN $\gamma$ secretion by CD4+ cells of patients on hemodialysis [25]. In contrast to our results, increased level of IL-10 accompanied by a transitory decrease of TNF $\alpha$ was observed in hemodialyzed patients receiving EPO for six months [24]. The discrepancy in the results may reflect difference in the experimental models, i.e. $24 \mathrm{hrs}$ incubation of PBMC from healthy subjects with EPO studied by us cannot be compared with the secretion by whole blood cells obtained from hemodialysis patients treated with EPO for 6 months. Comparable to our results, Cervelliniet al. [23] did not find any effect of EPO on IL- 6 or TNF $\alpha$ production by cells promoted for cytokine secretion either by TLR agonists, or by ATP activated inflammasomes. The authors concluded that the effect of EPO is likely to be indirect.
In the present study, EPO exerted a stimulatory effect on cytokine production when added to PBMC co-cultured with cancer cells. However, the results showed that cytokine production was both cell and concentration dependent. PBMC stimulated by RKO cells showed enhanced production of the pro-inflammatory cytokines IL-1 $\beta$, IL-6, IL-2, and IFN $\gamma$ observed predominantly using lower EPO concentrations. On the other hand, when PBMC were prompted by HT-29 cells, the effect of EPO on the examined cytokine production was almost absent except for an increase in $\mathrm{TNF} \alpha$ secretion. As for the anti-inflammatory cytokines surveyed in the study at the same laboratory settings, only the generation of IL-10 showed a mild increase, again at the lower doses of EPO.

In short, the results hereby reported demonstrate that while erythropoietin did not promote PBMC for cytokine production except for TNFa, co-culture of these cells with RKO colon cancer cells in the presence of the hormone caused an enhancement of the inflammatory IL-1 $\beta$, IL-6, IL- 2 and IFN $\gamma$ cytokine secretion by the immune cells. These findings enlighten the relationship between EPO, immune and colon cancer cells of certain lines.

\section{Acknowledgment}

We thank Ms. Ms. Tzippy Shochat, MSc, Statistical Consultant, Rabin Medical Center, Beilinson Hospital for her valued and continuous assistance in the statistical calculations.

\section{References}

1. Bunn HF. Erythropoietin. Cold Spring Harb Perspect Med. 2013;3(3):a011619.

2. Bahlmann FH, DeGroot K, Duckert T, Niemczyk E, Bahlmann E, Boehm SM, Haller H, et al. Endothelial progenitor cell proliferation and differentiation is regulated by erythropoietin. Kidney Int. 2003;64(5):1648-1652.

3. Lombardero M, Kovacs K, Scheithauer BW. Erythropoietin: a hormone with multiple functions. Pathobiology. 2011;78(1):41-53. doi: 10.1159/000322975

4. Prutchi-Sagiv S, Golishevsky N, Oster HS, Katz O, Cohen A, Naparstek E, Neumann D, Mittelman M, etal. Erythropoietin treatment in advanced multiple myeloma is associated with improved immunological functions: could it be beneficial in early disease? Br J Haematol. 2006;135(5):660-672.

5. Katz O, Gil L, Lifshitz L, Prutchi-Sagiv S, Gassmann M, Mittelman M, Neumann D, et al. Erythropoietin enhances immune responses in mice. Eur J Immunol. 2007;37(6):1584-1593.

6. Cravedi P, Manrique J, Hanlon KE, Reid-Adam J, Brody J, Prathuangsuk P, Mehrotra A, et al. Immunosuppressive effects of erythropoietin on human alloreactive T cells. J Am Soc Nephrol. 2014;25(9):2003-2015. doi: 10.1681/ASN.2013090945

7. Todosenko NM, Shmarov VA, Malashchenko VV, Meniailo ME, Melashchenko OB, Gazatova ND, Goncharov AG, et al. Erythropoietin exerts direct immunomodulatory effects on the cytokine production by activated human T-lymphocytes. Int Immunopharmacol. 2016;36:277-281. doi: 10.1016/j.intimp.2016.05.006 
8. Bryl E, Myśliwska J, Debska-Slizień A, Trzonkowski P, Rachoń D, Bułło B, Zdrojewski Z, et al. Recombinant human erythropoietin stimulates production of interleukin 2 by whole blood cell cultures of hemodialysis patients. Artif Organs. 1999; 23(9):809-816.

9. Spaan M, Groothuismink ZM, Koning L, Roomer R, Janssen HL, De Knegt RJ, Boonstra A. Erythropoietin administration suppresses human monocyte function in vitro and during therapy-induced anemia in HCV patients. Antiviral Res. 2013;98(3): 469-471. See comment in PubMed Commons below

10. Mittelman M, Neumann D, Peled A, Kanter P, Haran-Ghera N. Erythropoietin induces tumor regression and antitumor immune responses in murine myeloma models. Proc Natl Acad Sci U S A. 2001;98(9):5181-5186.

11. Mittelman M, Zeidman A, Kanter P, Katz O, Oster H, Rund D, Neumann D. Erythropoietin has an anti-myeloma effect - a hypothesis based on a clinical observation supported by animal studies. Eur J Haematol. 2004;72(3):155-165.

12. De Luisi A, Binetti L, Ria R, Ruggieri S, Berardi S, Catacchio I, Racanelli $\mathrm{V}$, et al. Erythropoietin is involved in the angiogenic potential of bone marrow macrophages in multiple myeloma. Angiogenesis. 2013;16(4):963-973. doi: 10.1007/s10456-013-9369-2

13. Tankiewicz-Kwedlo A, Pawlak D, Domaniewski T, Buczko W. Effect of erythropoietin, 5-fluorouracil and SN-38 on the growth of DLD-1 cells. Pharmacol Rep. 2010;62(5):926-937.

14. Chabowska A, Sulkowska M, Wincewicz A, Chabowski A, Mysliwiec M, Pawlak K, Koda M, et al. Serum erythropoietin and angiogenetic factors in human colorectal cancer. Prague Med Rep. 2007;108(4):348-357.

15. Macdougall IC, Cooper A. The inflammatory response and epoetin sensitivity. Nephrol Dial Transplant. 2002;17(Suppl 1):48-52.

16. Neumann U, Kunert C, Sperschneider H. The effect of erythropoietin (rh-EPO) on in vitro proliferation of granulocyte/monocytedetermined stem cells in bone marrow and peripheral blood. Med Klin (Munich). 1999;94(3):133-136.

17. Patterson SD, Rossi JM, Paweletz KL, Fitzpatrick VD, Begley CG, Busse L, Elliott S, et al. Functional EpoR pathway utilization is not detected in primary tumor cells isolated from human breast, nonsmall cell lung, colorectal, and ovarian tumor tissues. PLoS One. 2015;10(3):e0122149. doi: 10.1371/journal.pone.0122149
18. LaMontagne KR, Butler J, Marshall DJ, Tullai J, Gechtman Z, Hall C, Meshaw A, et al. Recombinant epoetins do not stimulate tumor growth in erythropoietin receptor-positive breast carcinoma models. Mol Cancer Ther. 2006;5(2):347-355.

19. Hardee ME, Kirkpatrick JP, Shan S, Snyder SA, Vujaskovic Z, Rabbani ZN, Dewhirst MW, et al. Human recombinant erythropoietin (rEpo) has no effect on tumour growth or angiogenesis. Br J Cancer. 2005;93(12):1350-1355.

20. Koçak FE, Erdoğan E, Ozyıgıt F, Yerlıkaya A. Evaluation of antiproliferative and antimetastatic effects of heparin and erythropoietin on B16f10 melanoma cell line. Cell Mol Biol (Noisy-legrand). 2013;59 Suppl: OL1894.

21. Reinbothe S, Larsson AM, Vaapil M, Wigerup C, Sun J, Jögi A, Neumann D, et al. EPO-independent functional EPO receptor in breast cancer enhances estrogen receptor activity and promotes cell proliferation. Biochem Biophys Res Commun. 2014;445(1):163-169. doi: 10.1016/j. bbrc.2014.01

22. Čubranić A, Dobrila-Dintinjana R, Redžović A, Dintinjana M, Petranović D, Golčić M. Endogenous erythropoietin and erythropoietin receptors in colorectal cancer; can we answer the questions? Med Hypotheses. 2016;96:16-19.

23. Cervellini I, Sacre S, Ghezzi P, Mengozzi M. Erythropoietin does not affect TNF and IL-6 production directly. J Biol Regul Homeost Agents. 2013;27(1):189-196.

24. Bryl E, Myśliwska J, Debska-Slizień A, Rachoń D, Bułło B, Lizakowski S, Myśliwski A, et al. The influence of recombinant human erythropoietin on tumor necrosis factor alpha and interleukin-10 production by whole blood cell cultures in hemodialysis patients. Artif Organs. 1998;22(3):177-181.

25. Lisowska KA, Dębska-Ślizień A, Jasiulewicz A, Daca A, Bryl E, Witkowski JM. The influence of recombinant human erythropoietin on apoptosis and cytokine production of CD4+ lymphocytes from hemodialyzed patients. J Clin Immunol. 2013; 33(3):661-665. 